\title{
Immersive Technologies in Media: Towards the Concept of Generative Mediatization?
}

\author{
Marina G. Shilina ${ }^{(1)} \bowtie$, Julia Wirth ${ }^{(2)}$ \\ ${ }^{(1)}$ Plekhanov Russian University of Economics, \\ 36 Stremyanny Ln, Moscow, 115093, Russian Federation \\ ${ }^{(2)} H E G$ Arc, HES-SO University of Applied Sciences and Arts Western Switzerland, \\ 21 Espace de l'Europe, Neuchâtel, 2000, Switzerland \\ $\bowtie$ marina.shilina@gmail.com
}

\begin{abstract}
The practices of so-called immersive media have been developing in the past few years. The immersive media situation characteristics, infrastructure, content and social aspects have been identified through the use of a multilevel structural and functional methodology, and make it possible to fix its specificity at all levels. The new format of the immersive media situation leads to changes in approaches to the mediatization studies. In the article, to study the media immersive communicative situation a generative approach is proposed for the first time. It is relevant to topological thinking, and to the modern immanent picture of the world, when a person and technology co-create a new form. Along with the generative approach and generative design, the necessity of applying relevant paradigms and methods of psychology to form new theoretical and methodological foundations of immersive user-centric media communication is substantiated. Several new concepts and terms are introduced, in particular, the term "immersive hypermediation", which is opposite to immediacy as a classical criterion of media effectiveness. As a result, the analysis of the essence and features of immersive media projects allows fixing the premises of immersive paradigm shift in mediatization studies.
\end{abstract}

Keywords: immersive communicative situation, transgression, prosumer of immersive media experience, immersive hypermedia, topological paradigm, immersive media reality, generative mediatization

Acknowledgements and Funding. This research was carried out within the framework of the project "Virtual digital experience: new visual communication for promotion of territory" funded by the Leading House for Swiss Science and Technology Cooperation with Russia and the CIS Region.

Conflicts of interest. The authors declare that there is no conflict of interest. 
Article history: submitted: May 10, 2021; accepted: June 11, 2021.

For citation: Shilina, M.G., \& Wirth, J. (2021). Immersive technologies in media: Towards the concept of generative mediatization? RUDN Journal of Studies in Literature and Journalism, 26(4), 672-680. doi: 10.22363/2312-9220-2021-26-4-672-680

\title{
Иммерсивные технологии в медиа: формируя концепцию порождающей медиатизации?
}

\author{
М.Г. Шилина ${ }^{(1)} \mathbb{D}^{凶}$, Ю. Вирт ${ }^{(2)}(\mathbb{E}$ \\ ${ }^{(1)}$ Российский экономический университет имени Г.В. Плеханова, \\ Российская Федерация, 115093, Москва, Стремянный пер., 36 \\ ${ }^{(2)}$ Высшая школа менеджмента Арк, \\ Университет прикладных наук Западной Швейцарии, \\ Швейцария, 2000, Невшатель, Espace de l'Europe 21 \\ $\bowtie$ marina.shilina@gmail.com
}

\begin{abstract}
Аннотация. Практики так называемой иммерсивной медийной коммуникации развиваются в последние несколько лет. Характеристики, инфраструктура, социальные аспекты иммерсивной медийной ситуации выявлены благодаря применению многоуровневой структурно-функциональной методологии и позволяют зафиксировать ее особость на всех уровнях. Новый формат иммерсивной медийной ситуации обусловливает изменения в подходах к изучению данной специфической персональной коммуникации. В статье впервые для исследования иммерсивной коммуникативной медийной ситуации предложен генеративный подход. Подход релевантен топологическому мышлению и современному представлению об имманентной картине мире, когда человек и технология становятся партнерами в процессе создания новой формы. Наряду с генеративным подходом и генеративным дизайном обоснована необходимость применения релевантных парадигм и методов психологии для формирования новых теоретикометодологических оснований иммерсивной медиакоммуникации, ориентированной на пользователя. Вводится ряд новых понятий и терминов. В частности, термин «иммерсивная гипермедиация» фиксирует редукцию иммедиации как классического критерия эффективности медиа. В итоге анализ сущности и особенностей иммерсивных медийных проектов позволяет зафиксировать предпосылки иммерсивной смены парадигмы в изучении медиатизации.
\end{abstract}

Ключевые слова: иммерсивная коммуникативная ситуация, трансгрессия, просьюмер иммерсивного медиаопыта, иммерсивная гипермедиация, топологическая парадигма, иммерсивная медиареальность, генеративная медиатизация

Благодарности и финансирование. Исследование проведено в рамках проекта «Виртуальный цифровой опыт: новая визуальная коммуникация для продвижения территории», финансируемого Ведущим Домом Швейцарского научно-технического сотрудничества с Россией и регионом СНГ.

Заявление о конфликте интересов. Авторы заявляют об отсутствии конфликта интересов. 
История статьи: поступила в редакцию - 10 мая 2021 г.; принята к публикации - 11 июня 2021 г.

Для цитирования: Shilina M.G., Wirth J. Immersive technologies in media: Towards the concept of generative mediatization? // Вестник Российского университета дружбы народов. Серия: Литературоведение. Журналистика. 2021. Т. 26. № 4. С. 672-680. doi: 10.22363/2312-9220-2021-26-4-672-680

\section{Introduction}

In the past decade, the emergence and spread of so-called immersive technologies such as augmented reality (AR), virtual reality (VR), mixed reality (MR) in the media have shaped the practice of media.

Immersive media projects imply a new, different from the traditional, format of interactive creation, receipt, consumption of media information and communication by an individual: for the first time in the history of media in immersive projects, a user becomes not just an individual prosumer (according to Toffler), but the prosumer of his own user experience (virtual, real, hybrid). The "immersive" prosumer can consume, create and vice versa creating, consume individually (including in games [1]) the content, in fact, in the format of an experiment. Thus, an object of an immersive project become a prosumer of an immersive media experience.

Immersive journalistic projects develop intensively in the 2010s (e.g. by Nonni della Peña, 2012). Nowadays, immersive journalism is a subcategory of journalism that uses technologies (e.g. VR) to provide engaging in such technologies with a sense of being wholly engrossed in the news story [2], thus allowing the audience to form an impression of the story [3].

In this article, we deliberately use broader non-journalistic but communication research optics, which allows focusing on the study of the immersive media communication situation as such. The immersive media communication situation within the framework of this study will be defined in its most general form as the interaction of situational elements and actors: the basic subject (customer of communication), creative subject (content creator), technical subject (ensuring the project functioning), and object (user). The elements are also the means and ways of implementing interaction, and the place of the project implementation.

What is the essence and specificity of the immersive communicative situation in the mediatization studies? The relevant literature analysis did not reveal complex answers to the posed research question.

Solving the scientific problem of identifying the features of the immersive media communication situation as a specific format of assemblage in mediatization studies is the aim of the study.

To identify the immersive communication situation specifics, there will be applied a multi-level methodology for studying the phenomena of social communication mediated by digital technologies, the Internet, artificial intelli- 
gence programs, which involves a step-by-step study of infrastructural, technical, technological and then social features of communication [4].

\section{Ontogenesis of immersion: Typology vs. topology?}

Immersion in various fields, from biology to mathematics, involves expanding the limits of the visible, a special type of spaces mapping, an increase in the most significant indicators, and a decrease in the visibility of defects and discontinuities, up to the mutual replacement of elements (e.g. in chemistry, atoms) of interacting media or a special mapping of topological spaces to each other. In other words, it is transgressive "by origin".

Researchers describe the genesis of modern immersive media projects, such as panoramic and $360^{\circ}$ photos or videos, starting with static ancient Roman panoramas [5]. The ideas of immersiveness as the basis for creating special virtual "worlds" were described in the literature of the 1930s (e.g. "Pygmalion's Glasses" by $\mathrm{S}$. Weinbaum).

In the digital age, immersive media projects (proto)ontogenesis is possible to study in the traditional paradigms of man-to-technology interaction as transindividual connection or in line with cybernetic traditions. The generative approach allows to involve users in creative communication and get new experiences. It is possible to consider the generative approach as the basis for understanding the essence and effects of all immersion formats, and generative design at the stages of technologies and projects research (and creation).

The generative approach's essence is clarified by the famous researcher of digitalization and architect Nicholas Negroponte. In the 1970s, Negroponte used the generative concept as the ability to create something new concerning architecture, and today his ideas are still relevant [6]. According to Negroponte, generative architecture should be created based on the interaction of an architect (subject) and a city dweller (non-architect, object), in order to adapt the environment using the residential building interface [7] (that is, the modern Internet of Things and the smart home concept).

Thus, the approach and the term reflect the integrative essence of both the man and technology interaction and the immersion of a person in a new virtual and "real" reality that he creates himself, including, as a result, cognitive and affective "production" of a new virtual, hybrid, and real experience.

The proposed approach is relevant to the modern concept of the immanent picture of the world, when a person and technology co-create a new form. This corresponds to the topological thinking characteristic of immersivity, as indicated above. In contrast to the traditional typological one, it determines the interaction of the topological spaces, and is aimed at optimizing the interaction of parts of the immersive media project as a system. In the context of media philosophy, immersive projects create a specific personalized immersive media reality. 


\section{Immersion: Immediation vs. hypermediation?}

De facto media are initially determined by various infrastructures and technologies the use of which is aimed at achieving maximum efficiency of impact on the audience with "seamless" consumption of communication.

Media traditionally uses three types of infrastructural and technical and technological "intermediaries" (communicative situation elements): tools and technologies to create a message; channels for the message delivery to the audience; media consumption tools [8]. An immersive media project at the infrastructural and technological levels is based on the digital technologies used to "immerse" the user who is in a physical space into a virtual or hybrid (virtual-real) space.

The technical infrastructure, thanks to which modern projects immerse the user in an immersive communicative situation, is diverse and multifunctional [9]. For example, the sensations from virtual reality are transmitted using a smartphone with a special VR application, tracking systems, mobile VR helmets, gloves, costumes, etc. The communication situation technical and technological elements are created for the most personalized communication and are adapted to the particular user's behavior through data analysis.

In the classical media, all "intermediaries" together form the consumer's media environment, where media communication is embodied and manifested [8].

In immersive media projects, a virtual-hybrid environment is formed based on the specific integration of convention and reality, which ensures interaction within all possible situations in media. For the first time, immersive projects provide a high level of simulation technology that is practically not used in other formats.

Multimodality of perception acts through various sensory modalities, on sight, hearing, touch. The immersive communication space can be designated as polysensory, which reflects the infrastructural, technological, and communicative aspects of project support.

How does the environment affect media effects? In the classical media, efficiency seems to be optimal with the "invisible" influence of media, immediacy. New criteria appear in immersive projects, in particular, because the "immersion" infrastructure and technologies are quite complex, the user needs to master a sufficiently large number of technology mediated "entry points" into virtuality, etc.

To describe such a situation, which in classical media studies is referred to as "hypermediation", we propose the term "immersive hypermediation". Immersive hypermediation captures the a priori plurality of channels, technologies, resources, carriers of an immersive media project (and it is opposite to immediacy as classical criteria for the media project effectiveness). 


\section{Immersion as a communication strategy: Rational vs. emotional?}

At the social interaction level, immersive projects are also specific, since individual immersive polysensory communication aims at the experimental creation of a new user experience, which distinguishes it from all other media practitioners.

The very attribution of the immersive media communication format is new. The classic dichotomy of interpersonal and mass communication in the digital era is being transformed, researchers fix a new dichotomy of interpersonal (faceto-face) and technology-mediated communication [8]. But the immersive experimental acquisition of real experience determines the need for allocation of a special immersive subcategory in the technology-mediated communication classification.

In terms of content, immersive media projects demonstrate the dominance of the long-established visualization trend as a consequence of the content strategies transition from rationality to emotional influence [3]. According to Novikov and Kiriya, "the audience is less and less interested in knowing what is happening in the territories controlled by ISIS. Modern journalism is trying to make the audience feel what is happening there" [10. P. 278].

De facto, the immersive media projects content satisfies all the key "classic" needs of the mass media audience: cognitive, affective, integrating rational and emotional requests, communicative, etc.

At the same time, the "experimental" way of immersive media content consuming satisfies the modern need for the "experience of presence" in a certain situation, time, and place. The topological paradigm allows the user to constantly reconstruct the situation, each time to receive new information, satisfying all new and diverse needs.

In the classical classification of digital information consumption formats, there are various formats, for example, linear or hypertext, planned or unplanned. In an immersive project, the content is multi-level and polysemantic, consumption is possible through planned and unplanned navigation, the spontaneity of the reaction provokes the spontaneity of the user creating a new story and new experience, obtaining new generative effects.

Thus, the immersive project's communication is personalized and experimental and constantly update. It is created in the generative topological paradigm, which determines the need to apply the relevant psychology paradigms in its study.

\section{Mediatization studies: Immersive media vs. new paradigm shift?}

The media and their effects as the sociocultural changes indispensable condition are considered by scientists in the paradigm of mediatization studies, 
especially since the 2010s. The mediatization studies concepts, which were declared as a paradigm shift in classical media studies, are inherently mediacentric, despite the statements about the distance from mediacentrism [11].

The practices and essence of the media's traditional "media-centricity" have long been undergoing radical transformations with the advent of the Internet, peer-to-peer communication, and mobile access. The user's involvement in mass interaction (the so-called Web 2.0), form a vast array of non-media or massmedia-centered, but "mass-personal" [12] or person-centered media.

The communicative situation of the personal interactive practices dominance, in fact, initially determined the need for the creation of relevant concepts in mediatization studies. However, to this day, the user-centric approach to mediatization studies has not found its comprehensive reflection; the existing concepts have been criticized largely for the lack of proper attention to the user as an object, despite the idea of "mediatization of everything" [11;13].

The dominance of personal media communication determines the need for a transition in mediatization studies from social optics, which has proven itself productively, to (socio) psychological ones, and generative approaches in media psychological research.

\section{Conclusion \& discussion}

Immersive media projects are a new communicative situation for media. Basic differences are noted at all levels: infrastructural, technical and technological, and social. At the communication level, information consumption becomes for the first time an experiment aimed at obtaining a new user experience. The user becomes not just a prosumer, but also an immersive media experience prosumer. The proposed term "immersive hypermediation" captures the radical multiplicity of channels, technologies, resources, carriers of an immersive media communication, and is opposite to immediacy as classical criteria for a media project effectiveness.

The immersive media communication essence is proposed to be investigated based on a generative approach, which reflects the communicative situation of creation, distribution, consumption based on immersive technologies of creative communication for the user to gain new experience.

To designate the research direction into the essence and effects of immersive media practices, the term "generative mediatization" is proposed, which we define as the effects of personal and socio-cultural development obtained by the user based on experience following participation in a creative immersive media project.

The immersive media situation determines changes in research approaches to the study of immersive user-centric media communication: the transition to relevant psychology methods. 
Thus, the analysis of the immersive media project's essence and features allows us to fix the prerequisites for a new format of media communication, which deepens the user-centric approach, and provokes a new paradigm shift in mediatization studies.

\section{References / Библиографический список}

[1] Volkova, I.I. (2014). Game formats of multimedia journalism. RUDN Journal of Studies in Literature and Journalism, (1), 105-112. (In Russ.)

Волкова И.И. Игровые форматы мультимедийной журналистики // Вестник Российского университета дружбы народов. Серия: Литературоведение, журналистика. 2014. № 1. С. 105-112.

[2] Friedman, D., \& Kotzen, C. (2018). Immersive Journalism: The New Narratives / Robot Journalism: Human Journalism Survive? (pp. 79-91).

[3] Ferjoux, C., \& Dupont, R.E. (2020). Journalisme immersif et empathie: l'émotion comme connaissance immédiate du réel. Communiquer. Retrieved May 25, 2021, from http:// journals.openedition.org/communiquer/5477;DOI10.4000/communiquer.5477

[4] Shilina, M.G. (2012). Textogenic Transformation of the Infosphere. A methodological Sketch of the Internet Growth. Moscow. (In Russ.)

Шилина М.Г. Текстогенные трансформации инфосферы. Методологический эскиз становления Интернета. М., 2012.

[5] Grau, O. (2013). Emotion and Immersion: Key Elements of Visual Research. Saint Petersburg: Eidos. (In Russ.)

Грау О. Эмоции и иммерсия: ключевые элементы визуальных исследований. СПб.: Эйдос, 2013.

[6] Deryughina, O. Immersive and Interactive Environments. Retrieved May 25, 2021, from https://redmuseum.church/deryugina-environments (In Russ.)

Дерюгина О. Иммерсивные и интерактивные среды. URL: https://redmuseum. church/deryugina-environments (дата обращения: 25.05.2021).

[7] Negroponte, N. (1970). The Architecture Machine. Cambridge, MIT Press.

[8] Kolomiets, V.P. (2019). Conceptualization of media communication. MediaScope, (4). Retrieved May 25, 2021, from: http://www.mediascope.ru/2575 DOI: 10.30547/media scope.4.2019.2 (In Russ.)

Коломиеи В.П. Концептуализация медиакоммуникации // Медиаскоп. 2019. № 4. URL: http://www.mediascope.ru/2575 DOI: 10.30547/mediascope.4.2019.2 (дата обращения: 25.05.2021).

[9] Flavián, C., Ibáñez-Sánchez, S., \& Orús, C. (2019). The impact of virtual, augmented and mixed reality technologies on the customer experience. Journal of Business Research, (100), 547-560. doi: 10.1016/j.jbusres.2018.10.050

[10] Novikova, A.A., \& Kiriya I.V. (2018). Aesthetics of immersiveness: Features of creativity of a journalist in multimedia and transmedia projects. Bulletin of St. Petersburg University. Language and Literature, 15(2), 276-288. doi: 10.21638/11701/ spbu09.2018.210 (In Russ.)

Новикова А.А., Кирия И.В. Эстетика иммерсивности: особенности творческой деятельности журналиста в мультимедийных и трансмедийных проектах // Вестник Санкт-Петербургского университета. Язык и литература. 2018. Т. 15. № 2. С. 276288. doi: 10.21638/11701/ spbu09.2018.210

[11] Livingston, S. (2008). Mediatization of Everything. 
[12] O’Sullivan, P.B., \& Carr, C.T. (2018). Masspersonal Communication: A Model Bridging the Mass-Interpersonal Divide. New Media \& Society, 20(3), 1161-1180. DOI: 10.1177/ 1461444816686104

[13] Artamonova, Y.D., \& Volodenkov, S.V. (2021) Mediatization as a research concept: Main prerequisites, the formation and possibilities for further development. Praema. Journal of Visual Semiotics, (2), 9-27. (In Russ.)

Артамонова Ю.Д., Володенков С.В. Медиатизация как исследовательский концепт: основные предпосылки, формирование и возможности дальнейшего развития. Praema // Журнал визуальной семиотики. 2021. № 2. С. 9-27.

\section{Bio notes:}

Marina G. Shilina, Professor, Plekhanov Russian University of Economics, Lomonosov Moscow State University, ORCID: 0000-0002-9608-352X; e-mail: marina.shilina@gmail.com Julia Wirth, Associate Professor, Haute ecole de gestion Arc, HES-SO University of Applied Sciences and Arts Western Switzerland. ORCID: 0000-0002-1006-9349; e-mail: Julia.wirth@he-arc.ch

\section{Сведения об авторах:}

Шилина Марина Григорьевна, профессор РЭУ имени Г.В. Плеханова, МГУ имени M.B. Ломоносова. ORCID: 0000-0002-9608-352X; e-mail: marina.shilina@gmail.com

Вирт Юлия, доцент Высшей школы менеджмента при Университете прикладных наук Западной Швейцарии. ORCID: 0000-0002-1006-9349; e-mail: Julia.wirth@ he-arc.ch 